\title{
Silicon foliar application on nutrition and growth of Phalaenopsis and Dendrobium orchids
}

\author{
Cibele Mantovani*, Renato de Mello Prado, Kathia Fernandes Lopes Pivetta \\ São Paulo State University (Unesp), School of Agricultural and Veterinarian Sciences, Jaboticabal, Path of Access Professor Paulo Donato Castellane, s/ $n^{o}$, Zip code 14884- \\ 900, Jaboticabal, Brazil
}

\section{A R T I C L E I N F O}

\section{Keywords:}

Orchid nutrition

$\mathrm{C} / \mathrm{Si}$ ratio

Stoichiometry

Orchidaceae

Si toxicity

\begin{abstract}
A B S T R A C T
Foliar application of silicon can be beneficial to orchid growth, but it may also impair growth depending on the source and solution concentration. Due to the lack of information on silicon toxicity in long-term orchid nutrition, experiment with two different orchid species, Phalaenopsis Golden Peoker and Dendrobium Valentine, were performed. The plants were grown in plastic trays with dry Sphagnum in a greenhouse, being fed the nutrient solution without silicon in the first six months. After that, the plants were transplanted to individual plastic vessels $(0.9 \mathrm{~L})$. The treatments followed a completely randomized design with a $5 \times 3$ factorial consisting of five Si concentrations (control, 14.3, 28.6, 42.9 and $57.2 \mathrm{mmol} \mathrm{L}^{-1}$ ) and three sources (monosilicic acid, potassium silicate, and potassium silicate and sodium silicate mixture), with five replicates. After $18 \mathrm{months}$ of $\mathrm{Si}$ foliar application, the $\mathrm{Si}, \mathrm{C}, \mathrm{N}, \mathrm{P}, \mathrm{K}, \mathrm{Ca}, \mathrm{Mg}$ and $\mathrm{S}$ levels, lignin content and biometric variables were determined for both species. The application of 27 and $16 \mathrm{mmol} \mathrm{L}^{-1} \mathrm{Si}$ (potassium silicate and monosilicic acid) resulted in the highest values for the evaluated biometric parameters for Phalaenopsis and Dendrobium, respectively. The results suggest that silicon foliar application affected nutrient absorption and green color index of Phalaenopsis and Dendrobium, and the lignin content of Phalaenopsis. Application of concentrations greater than 39 and $18 \mathrm{mmol} \mathrm{L}^{-1} \mathrm{Si}$ over 18 months was toxic to Phalaenopsis and Dendrobium, respectively, since the orchid dry matter decreased by $10 \%$ (critical level due to toxicity). Applying increasing concentrations of Si sources decreased the C:N:P stoichiometric ratio of orchids.
\end{abstract}

\section{Introduction}

There are several studies on orchid nutrition and fertilization in the literature (Naik et al., 2009; Wang and Chang, 2017) because orchid farming represents one of the most economically important activities of the global nursery industry (Teixeira da Silva, 2013). However, to our knowledge, there are no reports on the application of Si during the entire vegetative cycle.

In plant metabolism, silicon ( $\mathrm{Si}$ ) is involved in the synthesis of lignin, increasing tissue stiffness (Epstein, 1999), but, it is not known how excess Si would affect orchid growth.

Recent study in the literature correlated Si to the C:N:P stoichiometric change in grass leaves (Schaller et al., 2012), which may imply that organic compounds are partially replaced by $\mathrm{Si}$ compounds in plant tissue when $\mathrm{Si}$ is available to the plant, reinforcing the importance of Si. However, this relationship has not been investigated for perennial plants such as orchids.

There are report on Phalaenopsis orchids cultivated in vitro indicating growth benefit when $\mathrm{Si}$ is present in the culture medium (Zhou,
1995). However, Si may decrease plant growth under certain cultivation conditions as reported by Soares et al. (2008) for orchids (Hadrolaelia) while using sodium silicate as Si source during the acclimatization phase (8 months).

Also in Maize, $\mathrm{Si}$ in excess forms a thick silicate layer below the cuticle on the leaf epidermis (Kochanová et al., 2014) that may reduce plant gas exchange and biomass accumulation without causing oxidative stress. Therefore, unlike other toxicity stresses, excess Si may not trigger an increase of reactive oxygen resulting in oxidation of organic compounds such as proteins and lipids, inducing membrane damage and extravasation of the cytosol to the apparent free space of the cell, causing cell death (Fridovich, 1986; Marschner, 1995).

Other studies on $\mathrm{Si}$ are restricted to in vitro orchid cultivation (Sivanesan and Park, 2014) or the initial phase during the first month of plant growth (Phalaenopsis hybrids) (Vendrame et al., 2010). Furthermore, there are no reports on Si foliar application during the entire vegetative cycle that can last up to 18 months depending on the growth environment.

It is important to study not only the benefits of silicon but also its

\footnotetext{
* Corresponding author.

E-mail address: orquidariomantovani@gmail.com (C. Mantovani).
} 
possible detrimental effect on plants that absorb but do not accumulate $\mathrm{Si}$ such as orchids to improve the knowledge on the role that foliar $\mathrm{Si}$ plays on the growth of ornamental plants.

It has been hypothesized that Si via foliar applications can benefit the orchids, but excess can diminish nutrient absorption and plant growth without altering the leakage of cellular electrolytes and lignin contents depending on the Si source and solution concentration.

Therefore, the objective of the present study was to evaluate the response of epiphytic orchids to silicon foliar application from various sources each at several concentrations during the growth phase, from seedlings until pre-flowering.

\section{Material and methods}

The experiment was carried out in an orchid greenhouse located in Itapolis, São Paulo, Brazil. The used orchids, Phalaenopsis Golden Peoker and Dendrobium Valentine seedlings, were obtained via in vitro propagation and acclimatized in plastic trays filled with dry Sphagnum substrate. In the first six months, the plants were fertirrigated with the complete nutrient solution of Sarruge (1975) without Si, biweekly. Then, the seedlings were transplanted individually into black polyethylene vessels (upper diameter: $13 \mathrm{~cm}$, lower diameter: $8.4 \mathrm{~cm}$, height: $10.6 \mathrm{~cm}$ ) with $0.9 \mathrm{~L}$ volume.

The nutrient concentrations $\left(\mathrm{mg} \mathrm{L}^{-1}\right)$ in the solution was: $225 \mathrm{~N}$; 31 P; 234 K; $200 \mathrm{Ca} ; 48 \mathrm{Mg}$; 64 S; 0.5 B; $0.5 \mathrm{Mn} ; 0.05 \mathrm{Zn} ; 0.02 \mathrm{Cu} 0.01$ Mo; 5 Fe (Sarruge, 1975).

The plants were kept in a greenhouse with average Photosynthetic Photon Flux Density of $300 \mu \mathrm{mol} \mathrm{m}{ }^{-2} \cdot \mathrm{s}^{-1}$ at noon, and maximum and minimum temperatures of 34 and $15{ }^{\circ} \mathrm{C}$, respectively. The pots were filled with a layer of expanded clay at the bottom $(25 \%$ of the total volume) and with a 2:1 (v/v) mixture of pinus bark and charcoal medium, and placed on hanging tables at a height of $0.65 \mathrm{~m}$. The position of the pots was randomly changed after each treatment application, every 15 day.

The plants were irrigated twice and three times a week in the winter and summer, respectively, with $100 \mathrm{~mL}$ of distilled water $(\mathrm{pH}=6.8)$ per pot. The complete nutrient solution of Sarruge (1975) was applied separately in the substrate via fertirrigation, once a week.

The silicon was applied via foliar to two orchid species, the Phalaenopsis Golden Peoker and Dendrobium Valentine, following a $3 \times 5$ factorial scheme consisting of three sources and five $\mathrm{Si}$ concentrations. The treatments were as follows: control (zero), 14.3, 28.6, 42.9 and $57.2 \mathrm{mmol} \mathrm{L}^{-1} \mathrm{Si}$ from monosilicic acid (Zumsil ${ }^{T M}$ manufactured by TERRATECH CORP. in Miami, Florida, USA); potassium silicate (Sifol ${ }^{\circledR}$ manufactured by Diatom in Mogi das Cruzes, São Paulo, $\mathrm{BR}$ ) and potassium silicate and sodium silicate mixture. The experiment followed a completely randomized design with five replicates, and the experimental unit consisted of three plants, with one plant per pot.

The characteristics of the $\mathrm{Si}$ sources were density $=1.25$ and $\mathrm{Si}=79.3 \mathrm{~g} \mathrm{~L}^{-1}$ for monossilicic acid $\left(\mathrm{Zumsil}^{T M}\right.$ ); density $=1.41$, $\mathrm{Si}=168 \mathrm{~g} \mathrm{~L}^{-1}$, and $\mathrm{K}_{2} \mathrm{O}=211.5 \mathrm{~g} \mathrm{~L}^{-1}$ for potassium silicate $\left(\mathrm{Sifol}^{\oplus}{ }^{\circledR}\right.$; and density $=1.15 ; \mathrm{Si}=124 \mathrm{~g} \mathrm{~L}^{-1} ; \mathrm{K}_{2} \mathrm{O}=42.3 \mathrm{~g} \mathrm{~L}^{-1}$ and $\mathrm{Na}=31.6 \mathrm{~g}$ $\mathrm{L}^{-1}$ for the potassium silicate with sodium silicate mixture. The $\mathrm{pH}$ of the $\mathrm{Si}$ solution was adjusted to approximately 5.7 and 5.9 for all treatments.

The potassium concentrations were balanced with potassium chloride in all treatments. On the other hand, in the potassium silicate and sodium silicate mixture treatments, the sodium concentrations were balanced with sodium chloride.

Because orchids absorb nutrients and Si via foliar and roots, a solution volume sufficient to cover the total leaf area was applied on each plant using a micro-sprayer. This volume increased as plant developed (ranging from 30 to $50 \mathrm{~mL}$ per plant) while application frequency depended on the vegetative growth. The Si solution was sprayed every 30 days in the first six months and every 15 days in the last 12 months.

Eighteen months after Si application had started and the plants began flowering (the first stem emerged), the following parameters were measured: stem diameter $(\mathrm{mm})$ measured at $2 \mathrm{~cm}$ from the stem base using a digital caliper (Starrett ${ }^{\circledR}$ 727-2001 manufactured in Itu, São Paulo, BR); root length $(\mathrm{cm})$ measured the longer of aerial root in each plant; root volume $(\mathrm{mL})$ determined by the volumetric test method (Carrigan and Frey, 1980); leaf area $\left(\mathrm{cm}^{2}\right)$ obtained from all plant leaves using a digital meter (Li-Color, model L1-3000 ${ }^{\circledR}$ ); electrolyte leakage (Dionisio-Sese and Tobita, 1998), and green color index (using the portable OptiScience ${ }^{\circledast}$ chlorophyll meter model CCM-200, in the central part of the adaxial surface of the last fully developed leaf of each plant). The number of pseudobulbs and plant height $(\mathrm{cm})$ were determined only for Dendrobium Valentine while the number of leaves and plant width (corresponding to the distance between the apex of the last two fully expanded leaves, $\mathrm{cm}$ ) were measured only for Phalaenopsis Golden Peoker.

The orchids were divided into aerial part/shoot and root and dried in forced circulation oven at $65-70{ }^{\circ} \mathrm{C}$ temperature, until constant weight. The dry matter was determined. The plant material was ground to determine the $\mathrm{N}, \mathrm{P}, \mathrm{K}, \mathrm{Ca}, \mathrm{Mg}$ and $\mathrm{S}$ contents following the methodology described by Bataglia et al. (1983) and the C content by the Dumas method using the LECO $^{\circledR}$ CN628 carbon analyzer. The accumulation of $\mathrm{C}, \mathrm{N}, \mathrm{P}, \mathrm{K}, \mathrm{Ca}, \mathrm{Mg}$ and $\mathrm{S}$ in the aerial shoot was calculated based on the nutrient concentration and dry matter.

The silicon content in the leaf tissue was determined following the method proposed by Korndörfer et al. (2004), and multiplied by the dry matter to obtain Si levels in the shoot whereas the lignin content was determined by the Klason method (Silva and Queiroz, 2002).

The results were analyzed by the F-test at $1 \%$ and $5 \%$ probability. The polynomial regression was applied when significant for doses (D) while the means were compared by Tukey at $5 \%$, for sources (F), in which the same letters indicate that the values do differ for the same dosage among the sources (a, b, and c). The calculations were carried using the AgroEstat software (Barbosa and Maldonado, 2014).

\section{Results}

\subsection{Levels of nutrients and silicon}

In Phalaenopsis, the C levels decreased linearly in relation to monosilicic acid application (Si_Mono); increased quadratically with potassium silicate ( $\mathrm{Si}_{-} \mathrm{K}$ ) maximizing at $946.8 \mathrm{mg}$ per plant for $26.7 \mathrm{mmol} \mathrm{L}^{-1} \mathrm{Si}$; and, decreased quadratically with the potassium and sodium silicate mixture $\left(\mathrm{Si}_{-} \mathrm{K} / \mathrm{Na}\right)$ reaching a minimum at $235.2 \mathrm{mg}$ per plant for $77.3 \mathrm{mmol} \mathrm{L}^{-1} \mathrm{Si}$ (Fig. 1A). The N, K, Ca and Mg levels increased quadratically with increasing $\mathrm{Si}$ from the potassium silicate and the potassium and sodium silicate mixture. However, $\mathrm{Si}$ from the monosilicic acid did not affect N, K, Ca and Mg levels (Fig. 1B-F). The K levels were affected by the applied Si, reaching a maximum of $564.5 \mathrm{mg}$ per plant for the $27.6 \mathrm{mmol} \mathrm{L}^{-1} \mathrm{Si}$ (potassium silicate). The P, S, and Si levels increased quadratically with increasing $\mathrm{Si}$ levels, regardless of the source (Fig. 1C, G, and H).

The highest $\mathrm{Si}$ levels in Phalaenopsis were obtained for the $33.7 \mathrm{mmol} \mathrm{L}^{-1} \mathrm{Si}$ from the potassium and sodium silicate mixture, followed by $30.9 \mathrm{mmol} \mathrm{L}^{-1} \mathrm{Si}$ from potassium silicate, and $29.6 \mathrm{mmol}$ $\mathrm{L}^{-1} \mathrm{Si}$ from monosilicic acid (Fig. $1 \mathrm{H}$ ).

In Dendrobium, the C, N, K and S levels increased quadratically with increasing $\mathrm{Si}$ from monosilicic acid, and potassium and sodium silicate mixture while decreasing linearly with increasing $\mathrm{Si}$ from silicate potassium (Fig. 2A, B, D, and G). The $\mathrm{K}$ level reached up to $244.1 \mathrm{mg}$ per plant for $23.4 \mathrm{mmol} \mathrm{L}^{-1} \mathrm{Si}\left(\mathrm{Si}_{-} \mathrm{K} / \mathrm{Na}\right)$. The highest C levels were 1193.6 and $1155.7 \mathrm{mg}$ per plant recorded for monosilicic acid $\left(14.2 \mathrm{mmol} \mathrm{L}^{-1}\right.$ $\mathrm{Si})$ and potassium and sodium silicate mixture $\left(24.2 \mathrm{mmol} \mathrm{L}^{-1} \mathrm{Si}\right)$, respectively. The $\mathrm{P}, \mathrm{Ca}$ and $\mathrm{Mg}$ levels increased quadratically with increasing Si from monosilicic acid; decreased linearly with potassium silicate, and remained unchanged for the potassium and sodium silicate mixture (Fig. 2C, E, and F). 

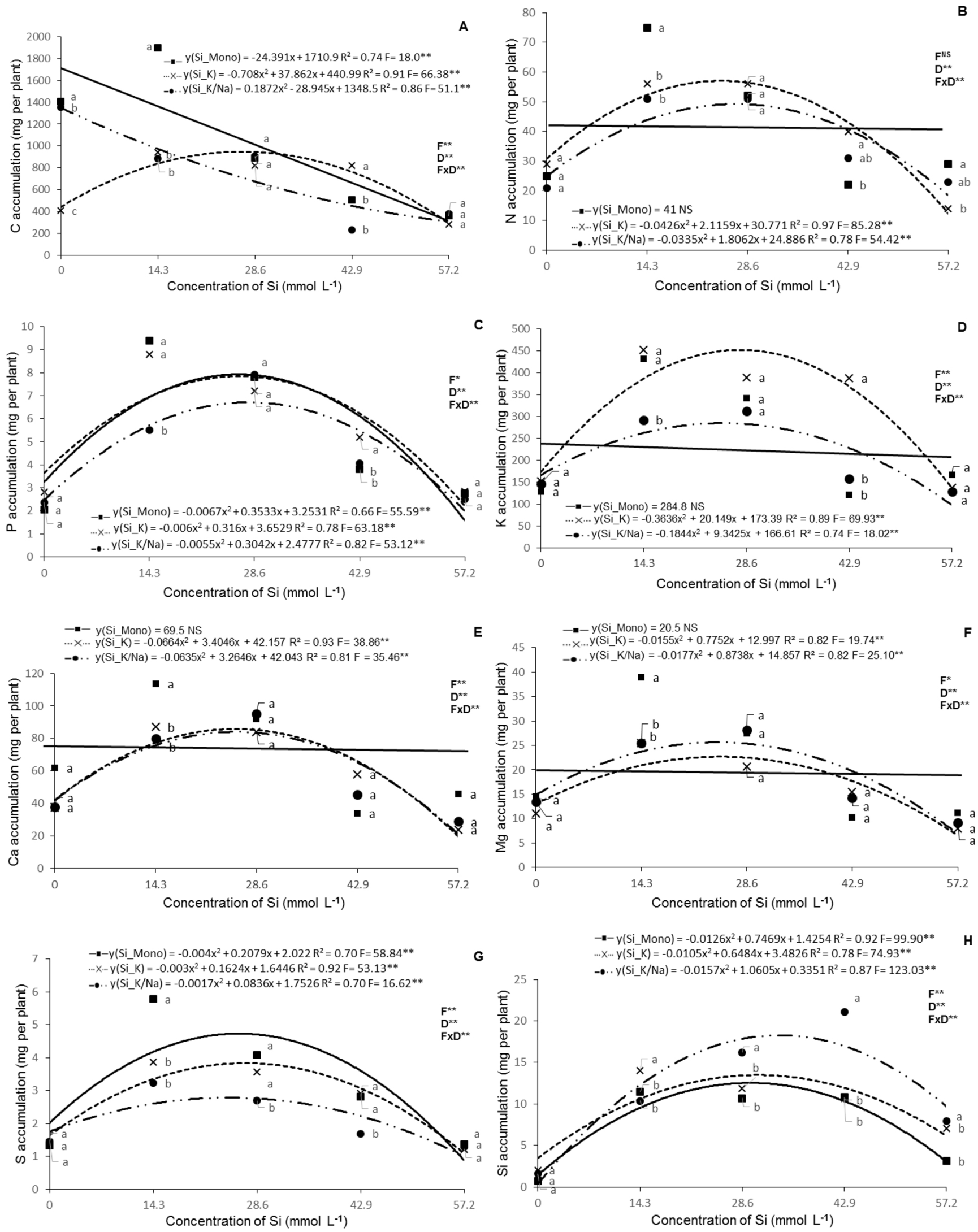

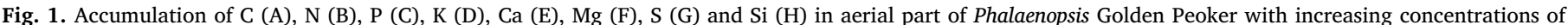

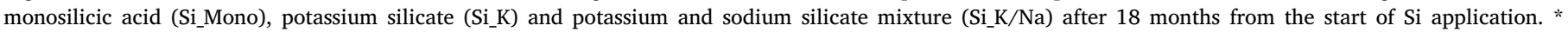
$\mathrm{p}<0,05 ;{ }^{* *} \mathrm{p}<0,01 ;{ }^{\mathrm{NS}}$ not significant by the F test. F to Si source, D to Si concentration and FxD to interaction. 


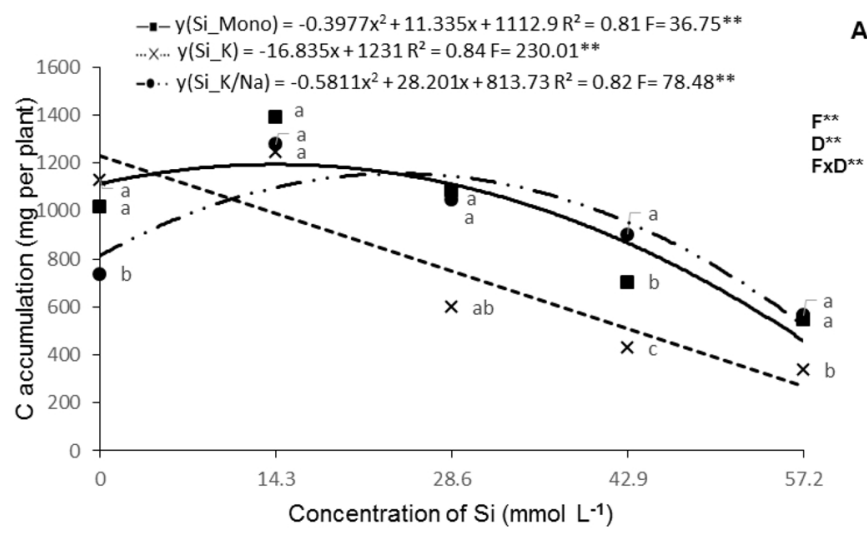

A
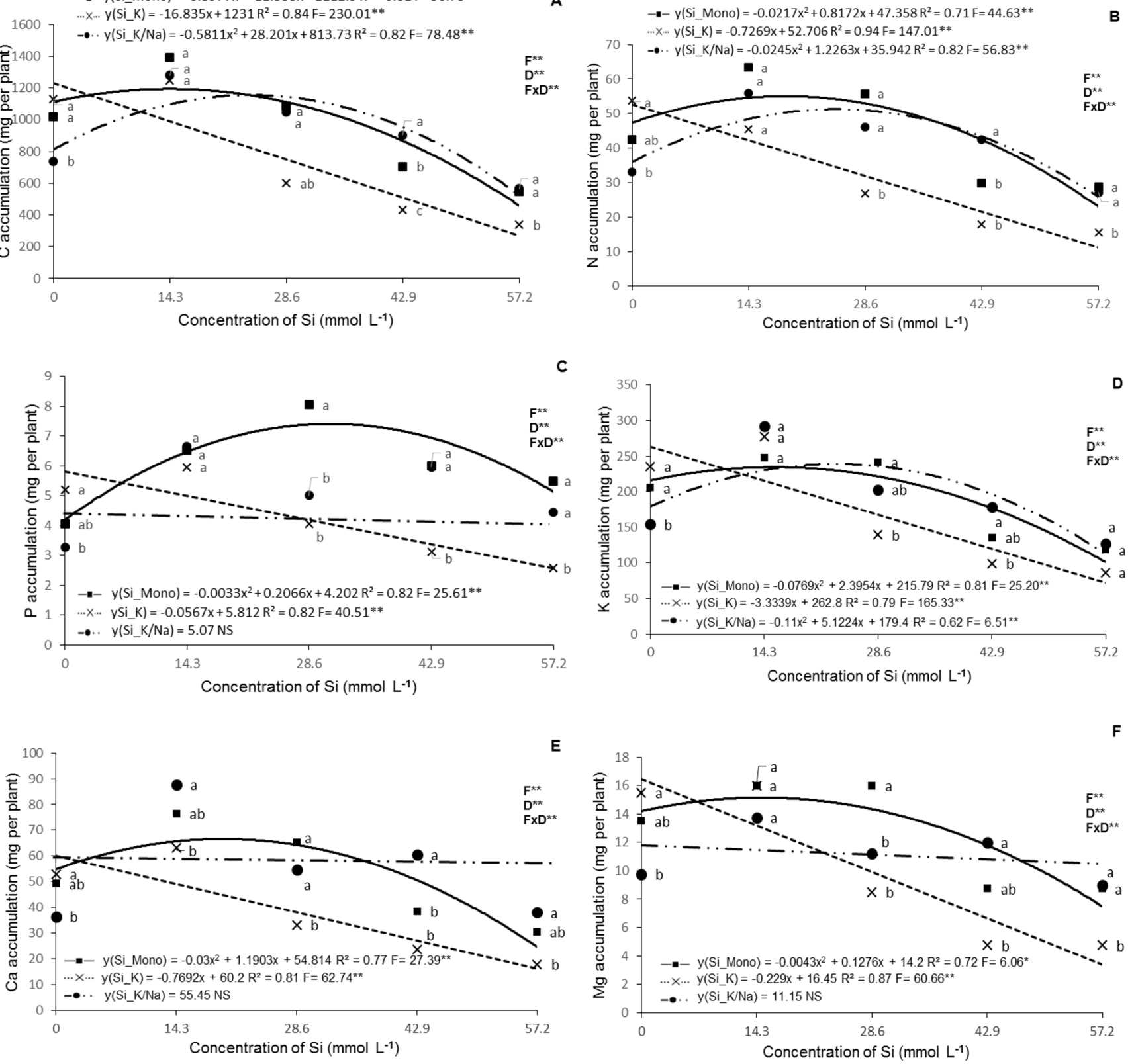

$\mathbf{E}$
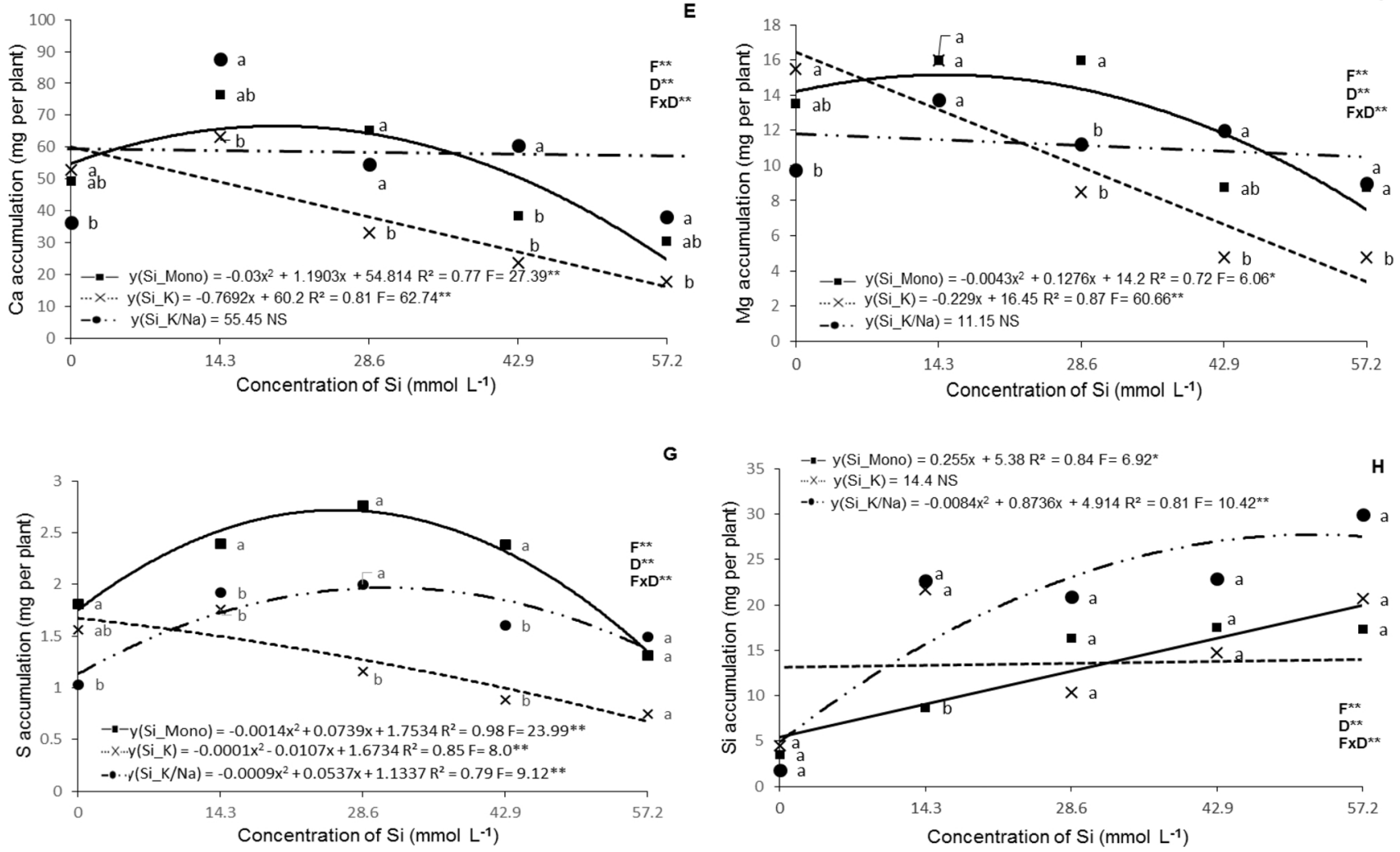

Fig. 2. Accumulation of C (A), N (B), P (C), K (D), Ca (E), Mg (F), S (G) and Si (H) in aerial part of Dendrobium Valentine with increasing concentrations of monosilicic acid (Si_Mono), potassium silicate (Si_K) and potassium and sodium silicate mixture (Si_K/Na) after 18 months from the start of Si application. ${ }^{* *} \mathrm{p}<0,01$; ${ }^{\mathrm{NS}}$ not significant by the F test. F to Si source, D to Si concentration and FxD to interaction. 


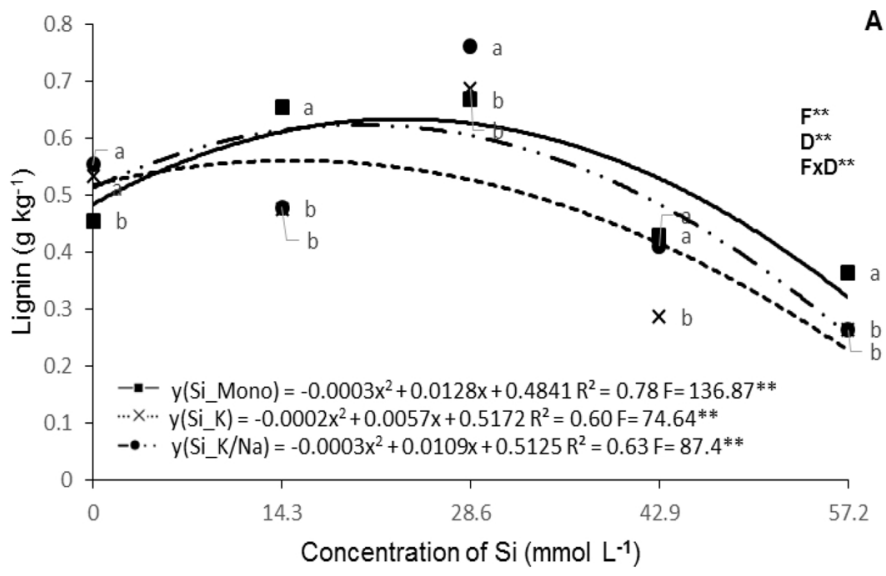

A
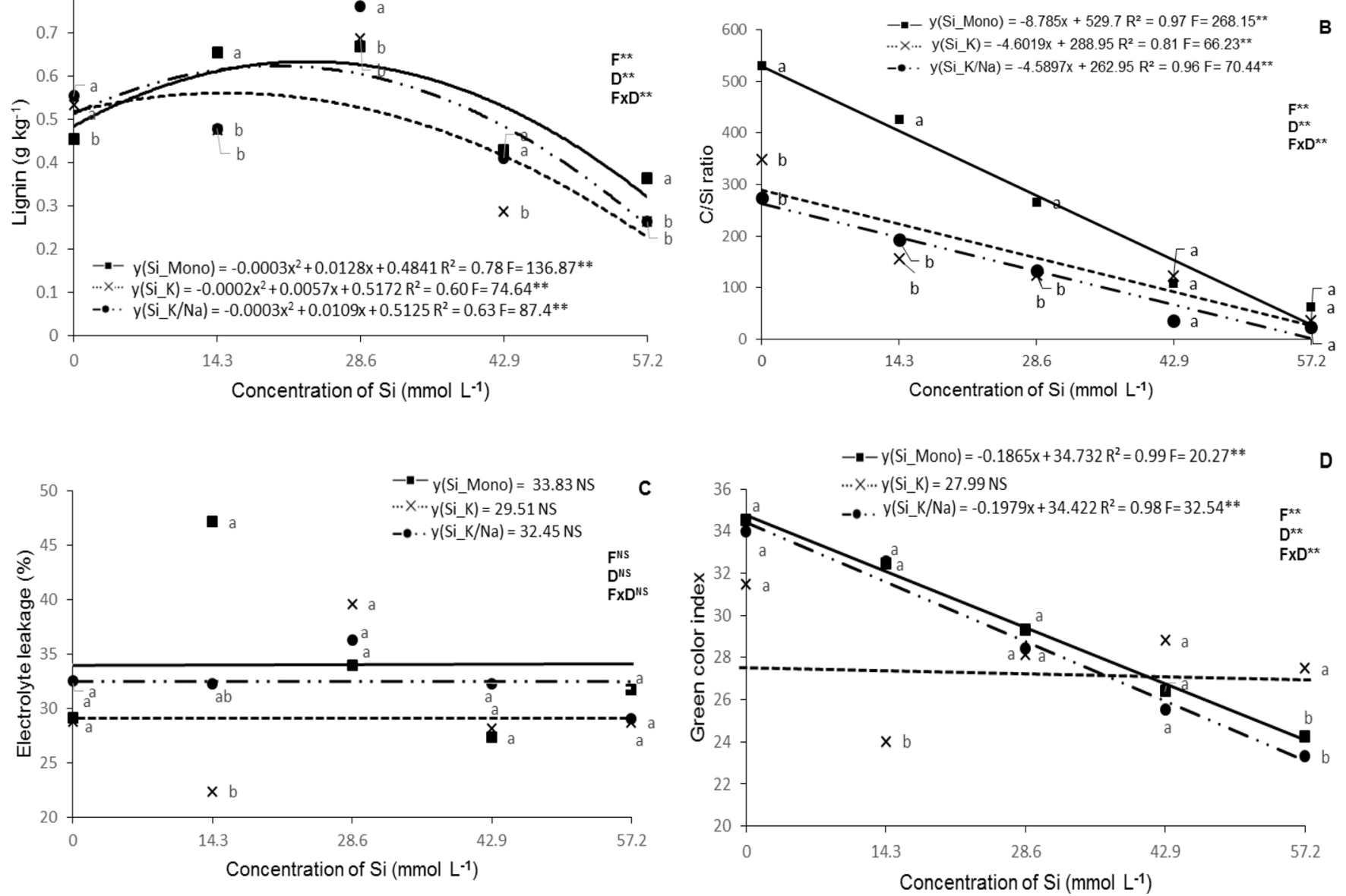

Fig. 3. Lignin content (A), C/Si ratio (B), electrolyte leakage (C) and green color index (D) in Phalaenopsis Golden Peoker with increasing concentrations of monosilicic acid (Si_Mono), potassium silicate $\left(\mathrm{Si}_{-} \mathrm{K}\right)$ and potassium and sodium silicate mixture $(\mathrm{Si} \mathrm{K} / \mathrm{Na})$ after 18 months from the start of $\mathrm{Si}$ application. ** $\mathrm{p}<0,01 ;{ }^{\mathrm{NS}}$ not significant by the F test. F to Si source, D to Si concentration and FxD to interaction.

The Si levels in Dendrobium increased linearly with increasing monosilicic acid, and quadratically with increasing potassium and sodium silicate mixture, reaching up to $27.62 \mathrm{mg}$ per plant for $52 \mathrm{mmol}$ $\mathrm{L}^{-1} \mathrm{Si}$ while remaining unchanged for increasing $\mathrm{Si}$ from potassium silicate (Fig. 2H).

\subsection{Lignin content, electrolyte leakage, stoichiometric ratio and green color index}

Phalaenopsis lignin content increased quadratically with increasing Si reaching $0.62,0.55$ and $0.61 \mathrm{~g} \mathrm{~kg}^{-1}$ for the $25,12.5$ and $18.2 \mathrm{mmol}$ $\mathrm{L}^{-1} \mathrm{Si}$ from monosilicic acid, potassium silicate, and potassium and sodium silicate mixture, respectively (Fig. 3A).

On the other hand, Dendrobium lignin content was affected by neither Si sources nor concentrations (Fig. 4A).

The $\mathrm{C} / \mathrm{Si}$ ratio decreased linearly and quadratically in the foliar tissue of Phalaenopsis (Fig. 3B) and Dendrobium (Fig. 4B), respectively, with increasing Si concentration from all sources tested. The C:N:P stoichiometric ratios decreased in the foliar tissue of Phalaenopsis and Dendrobium with increasing Si concentrations (Table 1 ).

The leakage of electrolytes in Phalaenopsis was not influenced by the different silicon sources or concentrations (Fig. 3C). In Dendrobium, electrolyte leakage increased quadratically reaching a maximum (34.8) for the $28.5 \mathrm{mmol} \mathrm{L}^{-1} \mathrm{Si}$ from the potassium and sodium silicate mixture (Fig. 4C).

Phalaenopsis green color index (GCI) decreased linearly with increasing Si from monosilicic acid, and potassium and sodium silicate mixture. However, it remained unchanged (27.99) with the potassium silicate application (Fig. 3D).

Dendrobium green color index decreased linearly with increasing $\mathrm{Si}$ from monosilicic acid and potassium and sodium silicate mixture. Furthermore, it increased quadratically with increasing potassium silicate concentrations, peaking at 32 for $16 \mathrm{mmol} \mathrm{L}^{-1} \mathrm{Si}$ (Fig. 4D).

\subsection{Effect of silicon on plant growth and development}

In Phalaenopsis, plant width, stem diameter, root length and number of leaves decreased linearly with increasing Si from monosilicic acid, and potassium and sodium silicate mixture. However, these parameters increased quadratically with increasing concentrations of potassium silicate reaching up to $35.5,16,22$, and 6 for 15, 19, 21 and $23 \mathrm{mmol}$ $\mathrm{L}^{-1} \mathrm{Si}$, respectively (Fig. $5 \mathrm{~A}-\mathrm{C}$, and $\mathrm{E}$ ).

The root volume decreased linearly with increasing $\mathrm{Si}$ concentrations and sources (Fig. 5D). The leaf area decreased linearly with the Si concentrations from monosilicic acid while increased quadratically with increasing Si from potassium silicate, and potassium and sodium silicate mixture (Fig. 5F).

Phalaenopsis dry matter increased quadratically for the Si sources and concentrations tested. The dry matter reached up to $3.4,4.1$ and $3.3 \mathrm{~g}$ for the application of $26,27.4$, and $21.8 \mathrm{mmol} \mathrm{L}^{-1} \mathrm{Si}$ from monosilicic acid, potassium silicate, and potassium and sodium silicate mixture, respectively. On the other hand, dry matter decreased $10 \%$ for the $39,39.6$ and $40.1 \mathrm{mmol} \mathrm{L}^{-1} \mathrm{Si}$ concentrations from the monosilicic acid, potassium silicate, and sodium and potassium silicate mixture sources, respectively (Fig. 5G).

Dendrobium mean plant height, root length and root volume 

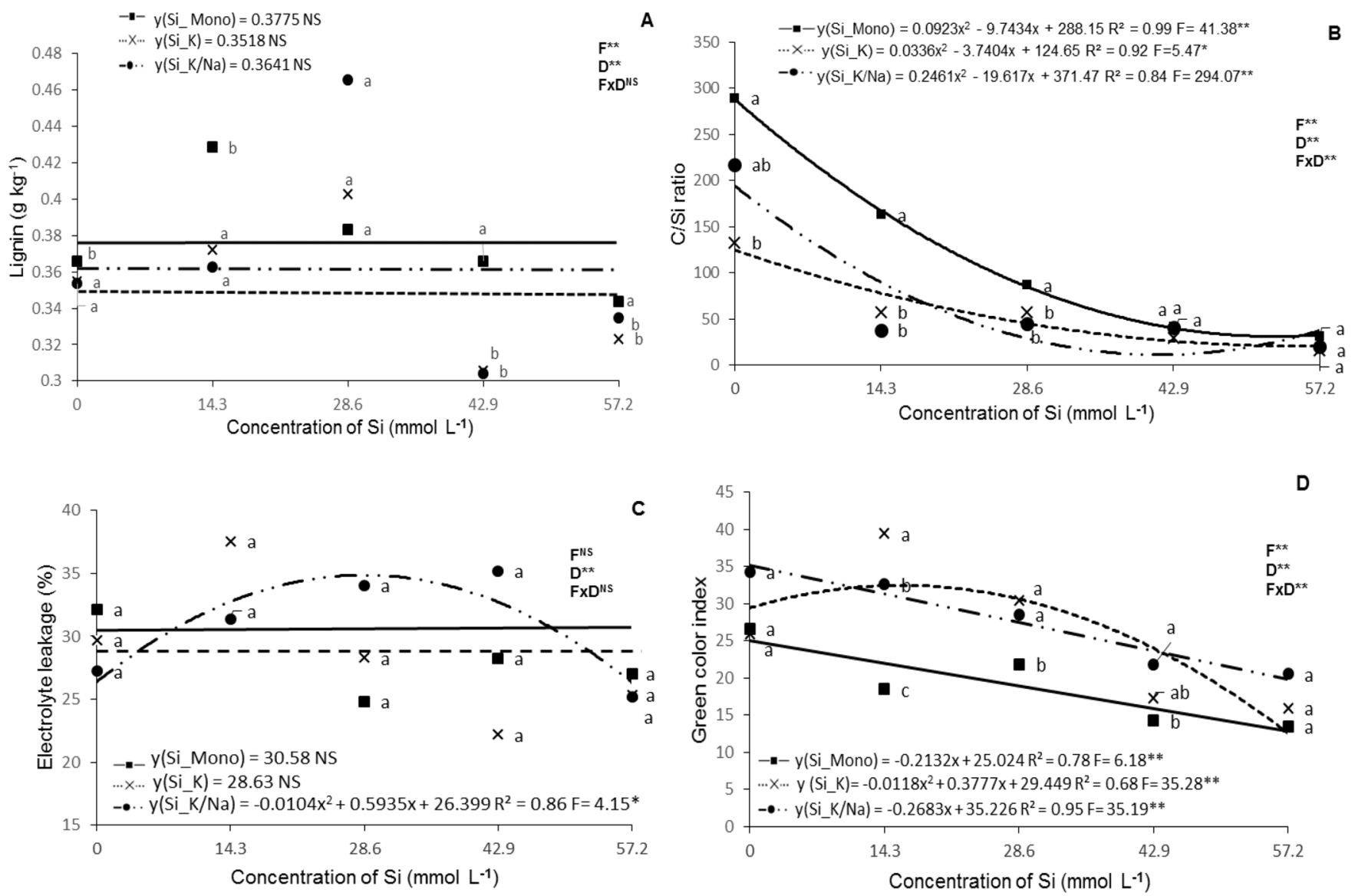

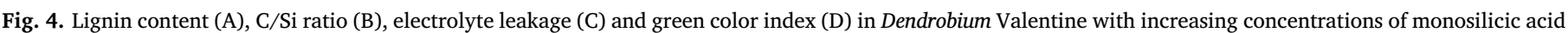

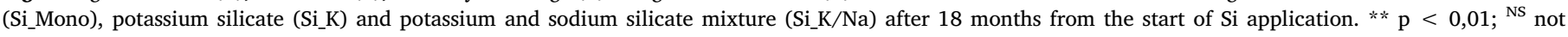
significant by the $\mathrm{F}$ test. $\mathrm{F}$ to $\mathrm{Si}$ source, $\mathrm{D}$ to $\mathrm{Si}$ concentration and $\mathrm{FxD}$ to interaction.

Table 1

C:N:P ratio for Phalaenopsis Golden Peoker and Dendrobium Valentine submitted to the application of monosilicic acid, potassium silicate, and potassium and sodium silicate mixture, after 18 months from the start of $\mathrm{Si}$ application.

\begin{tabular}{llll}
\hline $\begin{array}{l}\text { Concentrations of } \mathrm{Si} \\
(\mathrm{mmol} \mathrm{L}\end{array}$ & Monosilicic acid & $\begin{array}{l}\text { Potassium } \\
\text { silicate }\end{array}$ & $\begin{array}{l}\text { Potassium and } \\
\text { sodium silicate } \\
\text { mixture }\end{array}$ \\
\hline \multicolumn{2}{l}{ Phalaenopsis Golden Peoker } & & \\
0 & $199: 12: 1$ & $148: 11: 1$ & $177: 9: 1$ \\
14.3 & $151: 8: 1$ & $136: 8: 1$ & $158: 9: 1$ \\
28.6 & $133: 7: 1$ & $114: 8: 1$ & $116: 7: 1$ \\
42.9 & $132: 8: 1$ & $108: 5: 1$ & $105: 6: 1$ \\
57.2 & $133: 8: 1$ & $103: 5: 1$ & $126: 7: 1$ \\
Dendrobium Valentine & & & \\
0 & $252: 11: 1$ & $220: 9: 1$ & $229: 10: 1$ \\
14.3 & $216: 10: 1$ & $157: 7: 1$ & $222: 8: 1$ \\
28.6 & $134: 7: 1$ & $149: 7: 1$ & $195: 10: 1$ \\
42.9 & $118: 5: 1$ & $137: 6: 1$ & $152: 7: 1$ \\
57.2 & $99: 5: 1$ & $132: 6: 1$ & $128: 6: 1$ \\
\hline
\end{tabular}

decreased linearly with the increasing Si concentrations of the tested sources (Fig. 6A and C).

The Dendrobium stem diameter remained unchanged for the $\mathrm{Si}$ concentrations from the potassium and sodium silicate mixture, but decreased linearly with Si from monosilicic acid, and decreased quadratically with increasing $\mathrm{Si}$ concentrations from the potassium silicate (Fig. 6B).

The highest number of pseudobulbs in Dendrobium (5.6) was observed for the application of $25.4 \mathrm{mmol} \mathrm{L}^{-1} \mathrm{Si}$ from the potassium and sodium silicate mixture. The monosilicic acid and silicate potassium $\mathrm{Si}$ sources resulted in 4.1 and 4.4 pseudobulbs on average, for 11 and $9.1 \mathrm{mmol} \mathrm{L}^{-1} \mathrm{Si}$, respectively (Fig. 6E).

Dendrobium leaf area decreased linearly with increasing $\mathrm{Si}$ from monosilicic acid and potassium silicate while increasing quadratically for the potassium and sodium silicate mixture, reaching up to 57.9 for the $25 \mathrm{mmol} \mathrm{L}^{-1} \mathrm{Si}$ (Fig. 6F).

Dendrobium total dry matter decreased linearly with increasing Si concentrations from potassium silicate, and potassium and sodium silicate mixture, while increasing quadratically with increasing monosilicic acid concentrations (Fig. 6G).

The maximum dry matter $(3.1,3.16$ and $2.9 \mathrm{~g}$ ) contents were observed for $16.4,0$ and $0 \mathrm{mmol} \mathrm{L}^{-1} \mathrm{Si}$ from the monosilicic acid, potassium silicate, and potassium and sodium silicate mixture sources, respectively. On the other hand, the maximum dry matter content dropped $10 \%$ for the $17.6,8.2$ and $13 \mathrm{mmol} \mathrm{L}^{-1} \mathrm{Si}$ concentrations from monosilicic acid, potassium silicate, and potassium and sodium silicate mixture sources, respectively.

\section{Discussion}

\subsection{Nutrition}

In general, as the Si concentrations increased the level of nutrients decreased in Phalaenopsis and Dendrobium because the mineral content in the orchid tissue depends on fertilization (Naik et al., 2009) and probably Si competed with the other ions during absorption.

The present study demonstrated that Phalaenopsis and Dendrobium orchids absorbed and accumulated Si applied via foliar. However, studies involving foliar application of $\mathrm{Si}$ in orchids are incipient in the 

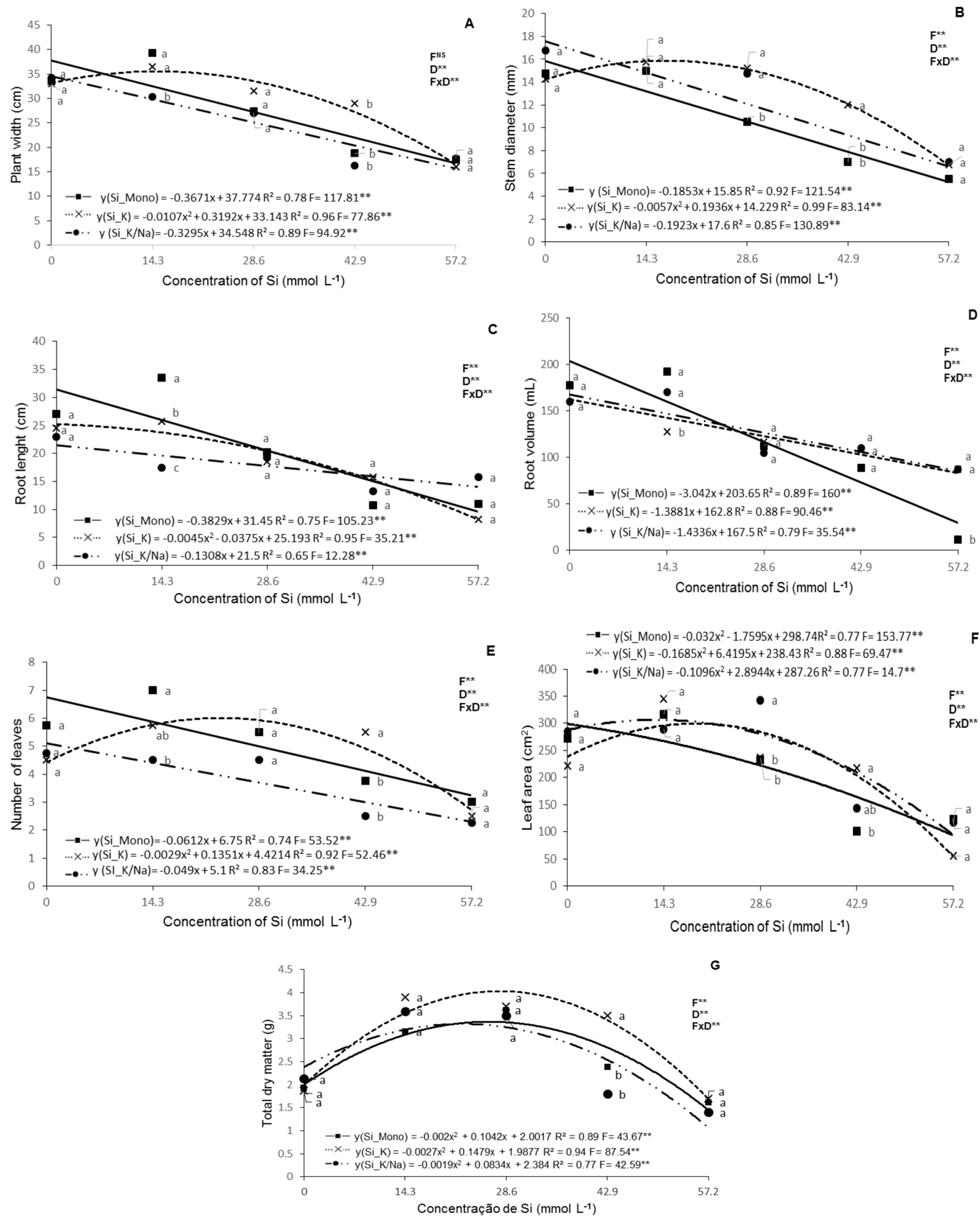

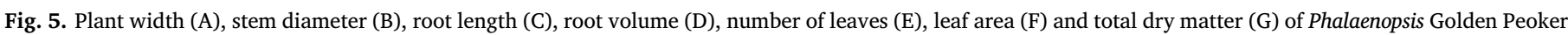

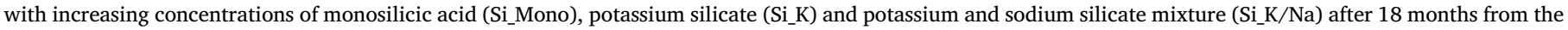
start of Si application. ${ }^{* *} \mathrm{p}<0,01$; ${ }^{\mathrm{NS}}$ not significant by the $\mathrm{F}$ test. F to Si source, D to Si concentration and FxD to interaction. 

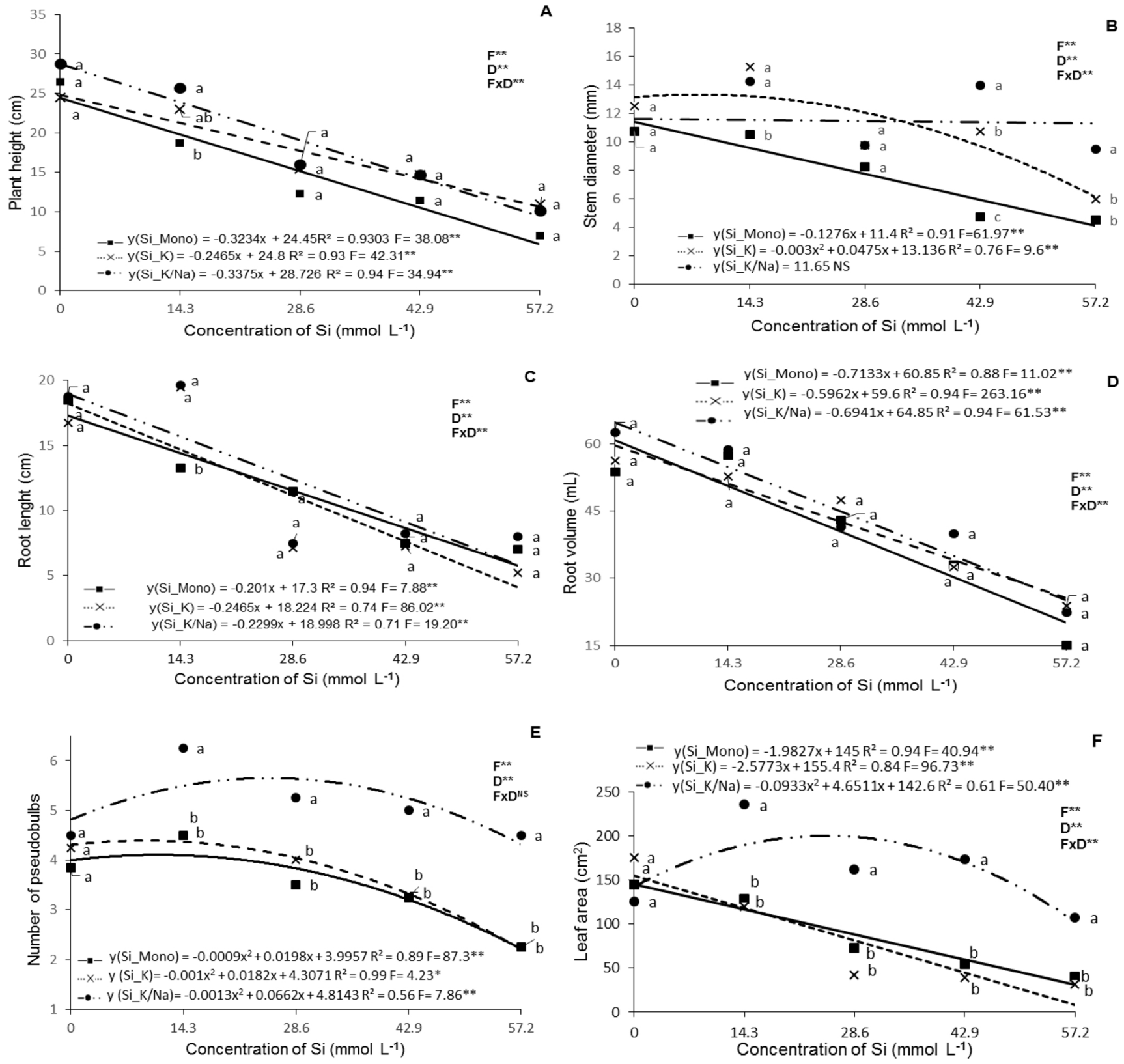

E
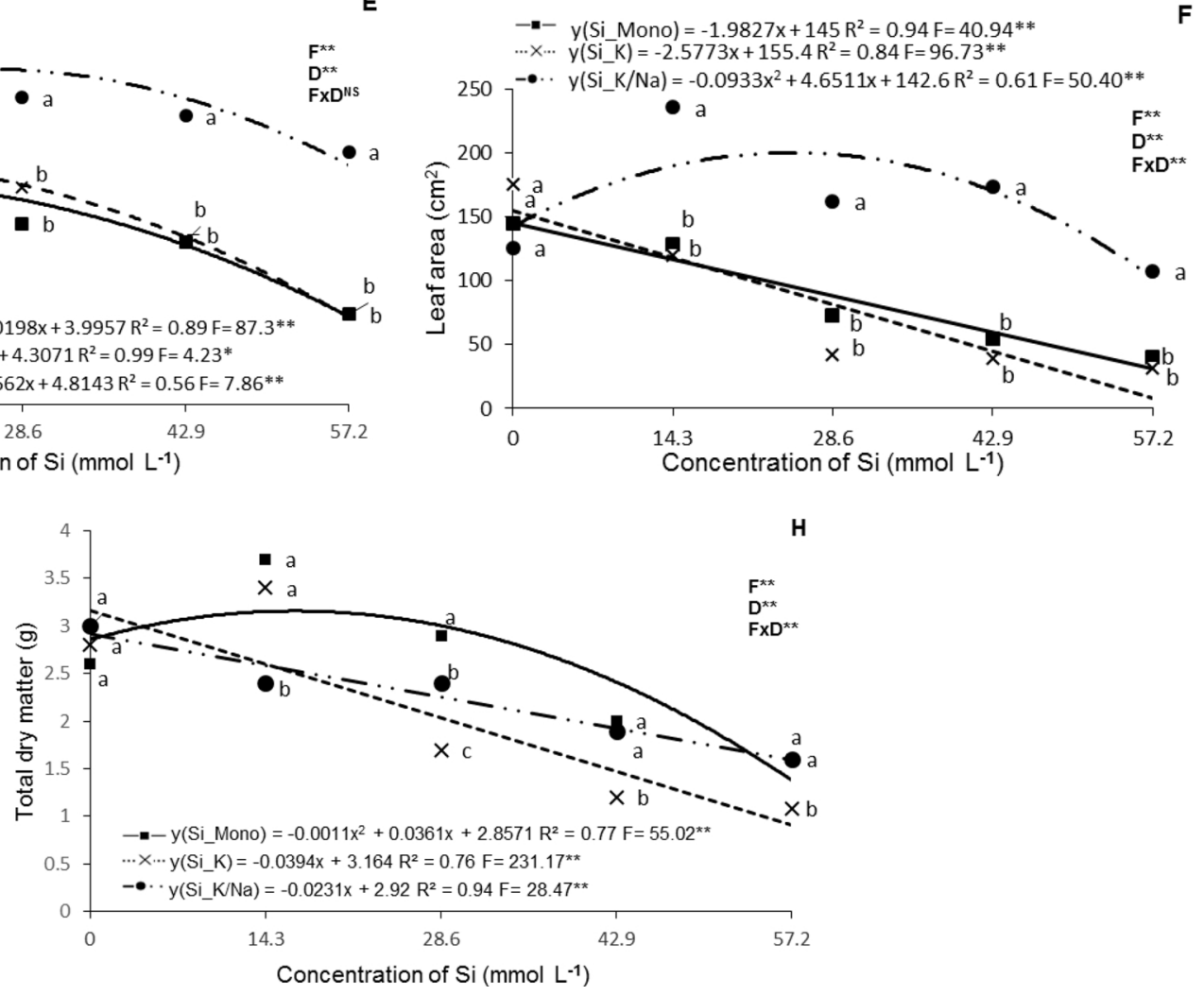

Fig. 6. Plant height (A), stem diameter (B), root length (C), root volume (D), number of pseudobulbs (E), leaf area (F) and total dry matter (G) for Dendrobium Valentine with increasing concentrations of monosilicic acid (Si_Mono), potassium silicate (Si_K) and a mixture of potassium silicate and sodium silicate (Si_K/Na), after 18 months from the start of Si application. ${ }^{* *} \mathrm{p}<0,01$; NS not significant by the F test. F to Si source, D to Si concentration and FxD to interaction. 
literature and, therefore, there is no information to compare the nutritional status of the orchids that have absorbed the Si with other works performed with orchids under different cultivation conditions and age.

The applied Si did not change the lignin content of Dendrobium. Likewise, Radomski (2006) studied the ornamental plant Maytenus ilicifolia and reported similar result after applying between 0 and $600 \mathrm{~kg}$ $\mathrm{Si} \mathrm{ha}{ }^{-1}$ in the soil for one year. Also, Fleck et al. (2015) evaluated the lignin content of rice, corn, and onion in the presence $\left(1.07 \mathrm{mmol} \mathrm{L}^{-1}\right)$ and absence of $\mathrm{Si}$ and reported similar conclusion.

However, for Phalaenopsis, the highest silicon concentrations resulted in lower $\mathrm{Si}$ accumulation in the aerial part and, consequently, the lowest lignin contents (Fig. 3A). Therefore, the effect of Si on the lignin content depends on the genotype and the accumulation of $\mathrm{Si}$ in the aerial part, being different for plants of the genus Phalaenopsis and Dendrobium.

Among others, $\mathrm{Si}$ is beneficial to plant metabolism since it contributes to keep the leaves photosynthetically active, increasing the chlorophyll synthesis and the green color index (GCI) only when supplying the ammonium $\mathrm{N}$ source (Campos et al., 2016). However, as observed in this work, under normal conditions of cultivation (without stress), the GCI decreased for both Phalaenopsis and Dendrobium for Si addition since Si can affect the protective effects of photosynthetic mechanisms, and nutrient balance, especially N (Mateos-Naranjo et al., 2013).

In the presence of this beneficial element there was increased activity of enzymes acting in the $\mathrm{N}$ metabolism, such as nitrate reductase, glutamine synthetase, glutamate synthetase and glutamate dehydrogenase (Bybordi, 2012; Feng et al., 2010). Nevertheless, the excess of $\mathrm{Si}$ impaired the $\mathrm{N}$ absorption by the orchids; likewise, Botelho et al. (2005) also demonstrated that Si application decreased N absorption.

Schaller et al. (2012) studied the Pragmites australis gramineous treated with increasing $\mathrm{Si}$ doses $(0,4.66$ and $46.6 \mathrm{~g}$ amorphous $\mathrm{Si}$ ) and reported modifications in the C:N:P stoichiometric ratios, as well. This result may be due to a partial substitution of organic compounds by $\mathrm{Si}$ compounds in the plant tissue, which is advantageous to the plant since silicon deposits require less energy to form and can confer lignin-like defenses (Schoelynck et al., 2010).

Therefore, the decreasing C, N, P contents observed for high Si doses may reflect the plant shifting to a defense mechanism that uses less energy in the presence of high Si concentrations (Schaller et al., 2012). This fact influenced the accumulation of other nutrients $(\mathrm{K}, \mathrm{Ca}, \mathrm{Mg}$ and $\mathrm{S})$ such as the decreasing $\mathrm{C} / \mathrm{Si}$ ratio observed in the foliar tissue.

\subsection{Growth and development}

Foliar application of $\mathrm{Si}$ at low concentrations had a positive effect on the growth of Phalaenopsis and Dendrobium possibly due to the better $\mathrm{Si}$ distribution and absorption compared to high concentration applications.

The physical parameters evaluated for both species of orchids had the worst results for the highest Si concentration evaluated, showing that Si toxicity decreased plant growth and development. This result corroborates the results reported by Soares et al. (2008) for a biweekly application of foliar potassium silicate and sodium silicate in the acclimatization of a hybrid Hadrolaelia lobata $\times$ Hadrolaelia purpurata steel orchid for eight months.

The mineral requirements of orchids vary with plant species and growth stages, therefore, the presented results show that Dendrobium Valentine Orchid is more sensitive to $\mathrm{Si}$ foliar application than Phalaenopsis Golden Peoker.

The highest Si concentrations applied to the leaf corresponded to the lowest average dry matter. Similar Si negative effect was verified by Vendrame et al. (2010) with the foliar application of potassium silicate to two Phalaenopsis cultivars.

Si concentrations higher than 39 and $18 \mathrm{mmol} \mathrm{L}^{-1} \mathrm{Si}$ (monosilicic acid) were considered as toxic critical levels for Phalaenopsis and Dendrobium, respectively, since the dry matter of orchids decreased by $10 \%$ (critical level due to toxicity).

In this study, the largest plant width $(35.5 \mathrm{~cm})$ for Phalaenopsis was obtained for $14.9 \mathrm{mmol} \mathrm{L}^{-1} \mathrm{Si}$ from potassium silicate during the ex vitro growth until the flowering. On the other hand, Zhou (1995) also observed increased size of Phalaenopsis leaves but with the addition of $0.1-1.0 \mathrm{mg} \mathrm{L}^{-1}$ calcium silicate to the culture medium during the in vitro culture phase.

Si toxicity decreased the number of pseudobulbs in Dendrobium, which according to $\mathrm{Ng}$ and Hew (2000), play an essential role in the growth and survival of orchids, accumulating water, mineral nutrients and carbohydrates, aiding the flowering and sprouting.

$\mathrm{Si}$ is accumulated as $\mathrm{H}_{4} \mathrm{SiO}_{4}$ (monosilicic acid) in the epidermal cells and walls of the stomata, but when the plant begins to lose water (water stress), this monomeric form becomes polymeric forms. Therefore, Si begins to form larger polysilicic acid chains, decreasing the flexibility of the stoma walls that tend to remain closed. The closed stomata decrease transpiration and water loss, which according to Faria (2000) decreases photosynthesis, possibly leading to lower development and, consequent, lower mass of orchids cultivated with high $\mathrm{Si}$ doses, as verified by Luz et al. (2006) for lettuce cultivation.

Another hypothesis regarding Si toxic effect would be that excess Si forms a thick silicate layer below the cuticle on the leaf epidermis (Kochanová et al., 2014). This layer may reduce plant gas exchange and biomass accumulation without causing oxidative stress, so that orchids submitted to the highest $\mathrm{Si}$ concentrations had lower accumulation of $\mathrm{Si}$ and nutrients, as well as lower performance of all biometric parameters evaluated.

\section{Conclusions}

Si concentrations of 27 and $16 \mathrm{mmol} \mathrm{L}^{-1}$ from potassium silicate and monosilicic acid sources are beneficial to growth of Phalaenopsis and Dendrobium, respectively.

The Si foliar application at concentrations higher than 39 and $18 \mathrm{mmol} \mathrm{L}^{-1}$ in Phalaenopsis and Dendrobium orchids, respectively, for 18 consecutive months caused Si toxicity in the plants without altering the electrolyte leakage.

\section{Appendix A. Supplementary data}

Supplementary material related to this article can be found, in the online version, at doi:https://doi.org/10.1016/j.scienta.2018.06.088.

\section{References}

Barbosa, J.C., Maldonado, J.R.W., 2014. AgroEstat - System for Statistical Analysis of Agronomic Trials - Version 1.1.0.711. Jaboticabal: Faculty of Agrarian and Veterinary Sciences, Universidade Estadual Paulista.

Bataglia, O.C., Furlani, A.M.C., Teixeira, J.P.F., Furlani, P.R., Gallo, J.R., 1983. Methods of chemical analysis of plants. Campinas: Instituto Agronômico de Campinas. Tech. Bull. 78, 48 .

Botelho, D.M.S., Pozza, E.A., Pozza, A.A.A., Carvalho, J.G., Botelho, C.E., Souza, P.E., 2005. Intensity of cercosporiosis in coffee seedlings due to sources and doses of silicon. Fitopatologia Brasileira 30, 582-588.

Bybordi, A., 2012. Effect of ascorbic acid and silicium on photosynthesis, antioxidant enzyme activity, and fatty acid contents in canola exposure to salt stress. J. Integr. Agric. 11, 1610-1620.

Campos, C.N.S., Prado, R.M., Caione, G., de Lima Neto, A.J., Mingotte, F.A.L.C., 2016. Silicon and excess ammonium and nitrate in cucumber plants. Afr. J. Agric. Res. 11, 276-283.

Carrigan, L., Frey, K.J., 1980. Root volumes of Avena species. Crop Science 20, 407-408.

Dionisio-Sese, M.L., Tobita, S., 1998. Antioxidant responses of rice seedlings to salinity stress. Plant Sci. 135, 1-9.

Epstein, E., 1999. Silicon. Annu. Rev. Plant Physiol. Plant Mol. Biol. 50, 641-664.

Faria, R.J., 2000. Influence of Calcium Silicate on the Tolerance of Rainfed Rice to Soil Water Deficit. Master'S Thesis. Federal University of Lavras, Lavras, Brasil 47p.

Feng, J., Shi, Q., Wanga, X., Wei, M., Yang, F., Xu, H., 2010. Silicon supplementation ameliorated the inhibition of photosynthesis and nitrate metabolism by cadmium (Cd) toxicity in Cucumis sativus L. Scientia Hortic. 123, 521-530. 
Fleck, A.T., Schulze, S., Hinrichs, M., Specht, A., Waßmann, F., Schreiber, L., Schenk, M.K., 2015. Silicon promotes exodermal casparian band formation in Si-accumulating and Si-excluding species by forming phenol complexes. PloS One 10, e0138555.

Fridovich, I., 1986. Biological effects of the superoxide radical. Arch. Biochem. Biophys. 247, 1-11.

Kochanová, Z., Jašková, K., Sedláková, B., Luxová, M., 2014. Silicon improves salinity tolerance and affects ammonia assimilation in maize roots. Biologia 69, 1164-1171.

Korndörfer, G.H., Pereira, H.S., Nolla, A., 2004. Silicon analysis: soil, plant and fertilizer. Technical Bulletin. Institute of Agrarian Sciences. Federal University of Uberlândia, Uberlândia MG, pp. 2.

Luz, J.M.Q., Guimarães, S.T.M.R., Korndörfer, G.H., 2006. Hydroponic production of lettuce in nutritive solution with and without silicon. Horticultura Brasileira 24, 295-300.

Marschner, H., 1995. Part I. Nutritional physiology. In: In: Marschner, H. (Ed.), Mineral Nutrition of Higher Plants Vol. 313-363. Academic Press Limited, London, pp. 18-30.

Mateos-Naranjo, E., Andrades-Moreno, L., Davy, A.J., 2013. Silicon alleviates deleterious effects of high salinity on the halophytic grass Spartina densiflora. Plant Physiol. Biochem. 63, 115-121.

Naik, S.K., Ush, T., Arathi, D.B., Devadas, R., Pal, R., Medhi, R.P., 2009. Status of mineral nutrition of orchid-a review. J. Ornament. Hortic. 1, 1-14.

Ng, C.K.Y., Hew, C.S., 2000. Orchid pseudobulbs-false'bulbs with a genuine importance in orchid growth and survival. Scientia Horticult. 83, 165-172.

Radomski, M.I., 2006. Foliar Contents of Silicon, Tannins and Lignin, in Maytenus ilicifolia Martius ex Reiss. (Espinheira-Santa), According to Environmental and Genetic
Variables. Doctoral Thesis. Paulista State University, Botucatu, Brasil.

Sarruge, J.R., 1975. Nutrition solutions. Summa Phytopathol. 1, 231-233.

Schaller, J., Brackhage, C., Gessner, M.O., Bäuker, E., Gertdudel, E., 2012. Silicon supply modifies C:N:P stoichiometry and growth of Phragmites australis. Plant Biol. 14, 392-396.

Schoelynck, J., Bal, K., Backx, H., Okruszko, T., Meire, P., Struyf, E., 2010. Silica uptake in aquatic and wetland macrophytes: a strategic choice between silica, lignin and cellulose? New Phytol. 186, 385-391.

Silva, D., Queiroz, A.D., 2002. Food Analysis: (Chemical and Biological Methods), 3 ed. UFV, Impr. Univ. 235 pp.

Sivanesan, I., Park, S., 2014. The role of silicon in plant tissue culture. Front. Plant Sci. 5, 571.

Soares, J.D.R., Pasqual, M., Rodrigues, F.A., Villa, F., Carvalho, J.D., 2008. Fertilization with foliar silicon in the acclimatization of an orchid hybrid. Ciência e Agrotecnologia 32, 626-629.

Teixeira da Silva, J., 2013. Orchids: advances in tissue culture, genetics, phytochemistry and transgenic biotechnology. Floricult. Ornament. Biotechnol. 7, 1-52.

Vendrame, W.A., Palmateer, A.J., Pinares, A., Moore, K.A., Datnoff, L.E., 2010. Silicon fertilization affects growth of hybrid Phalaenopsis orchid liners. HortTechnology 20, 603-607.

Wang, Y.T., Chang, Y.C.A., 2017. Effects of nitrogen and the various forms of nitrogen on Phalaenopsis Orchid-a review. HortTechnology 27, 144-149.

Zhou, T., 1995. The detection of the accumulation of silicon in Phalaenopsis (Orchidaceae). Annu. Bot. 75, 605-607. 